\title{
Hydrogenation Mechanism of Coal Tar Pitch for Carbon Fiber (Part 2) Hydrogen Transfer Mechanism from Tetralin to Coal Tar Pitch for High Performance Carbon Fiber Using Tritium Tracer Method
}

\author{
Hiroaki Shono $^{\dagger 2)}$, Motoi Marumoto ${ }^{\dagger 2)}$, Atsushi Ishihara ${ }^{\dagger 1)}$, \\ and Toshiaki $\mathrm{KABE}^{\dagger 1}$ *) \\ 11) Department of Chemical Engineering, Faculty of Technology, Tokyo University \\ of Agriculture and Technology, Nakamachi, Koganei, Tokyo 184 \\ †2) Mineral Fiber Res. Lab., Nitto Boseki Co., Ltd., Higashi Gonome, Fukushima, Fukushima 960
}

(Received September 14, 1989)

\begin{abstract}
Behavior of hydrogen in hydrogenation of the coal tar pitch for high performance carbon fiber with tetralin was investigated in temperature range of 410 to $470^{\circ} \mathrm{C}$ for $60 \mathrm{~min}$ using tritium tracer technique to elucidate the mechanism of hydrogen transfer. The amount of tritium transferred from tetralin to the pitch increased with rise in reaction temperature while the amount of hydrogen added from tetralin to the pitch was kept at almost constant value in temperature range of 410 to $470^{\circ} \mathrm{C}$. At $410^{\circ} \mathrm{C}$, the THFIS fraction decreased from $13.6 \mathrm{wt} \%$ to $5 \mathrm{wt} \%$ of the raw pitch, which was kept constant independent of the reaction temperature. HIS-BS fraction, increasing with rise in temperature from 410 to $450^{\circ} \mathrm{C}$, was the main product at $450^{\circ} \mathrm{C}$. Tetralin solvent began to decompose at $470^{\circ} \mathrm{C}$ and substantial hydrogen exchange reaction proceeded between pitch and tetralin.
\end{abstract}

\section{Introduction}

A number of attempts have been made to develop the utilization of heavy carbon resources. Among them, much attention has been focused on the utility of pitch and coal liquid and others as a raw material for a carbon fiber ${ }^{1) \sim 3)}$. Generally, it has been well-known that hydrogenation of pitch could be one of the important and effective methods to make a precursor for mesophase pitch $^{4}$, which gives a high performance carbon fiber $(\mathrm{HPCF})^{5)}$ 7). Yamada and others have reported that carbonaceous mesophases were prepared from vacuum-distillation residual oils by pyrolysis at $420^{\circ} \mathrm{C}$ and extraction of pitches formed with quinoline to obtain insoluble beads. The mesophase beads were hydrogenated in the presence of 1,2,3,4-tetrahydroquinoline to give a soluble component containing optically anisotropic micrograins ${ }^{8}$. There have been few examples, however, of hydrogen mobility of coal tar pitch being quantitatively investigated in hydrogenation of pitch. We have already reported on the quantitative estimation of hydrogen transfer in the hydrogenation of $\operatorname{coals}^{9), 10)}$ and coal liquids ${ }^{11)}$ using a tritium tracer method. Further, we have

* To whom correspondence should be addressed. recently investigated the hydrogenation of coal tar pitch for HPCF, with tritium labelled gaseous hydrogen to estimate hydrogen mobility in pitch ${ }^{12}$.

In the present paper, the coal tar pitch for HPCF was hydrogenated by tritium labelled tetralin. We report here completely different results from those of hydrogenation of pitch using gaseous hydrogen.

\section{Experimental Section}

\subsection{Materials}

The coal tar pitch for high performance carbon fiber was the same as that presented in previous paper ${ }^{12)}$ and its elemental analysis results were $\mathrm{C}$, 92.3; H, 4.9; N, 1.0; O (diff.), 1.8 wt\%. Hydrogen distributions of coal tar pitch by ${ }^{1} \mathrm{H}$ NMR spectroscopy and its composition by solvent fractionation were cited in previous paper ${ }^{12)}$. Tetralin obtained from commercial sources (extra pure grade) was used without further purification. Tritium labelled tetralin was added to unlabelled tetralin, and the initial concentration of tritium in solvent was controlled at $50,000 \mathrm{dpm} / \mathrm{g}$.

\subsection{Procedure of Hydrogenation Reaction with} Tritium Labelled Tetralin

The hydrogenation reaction was conducted by tritium labelled tetralin without catalyst. Coal tar pitch $(60 \mathrm{~g})$ and tritium labelled tetralin (120 g) 


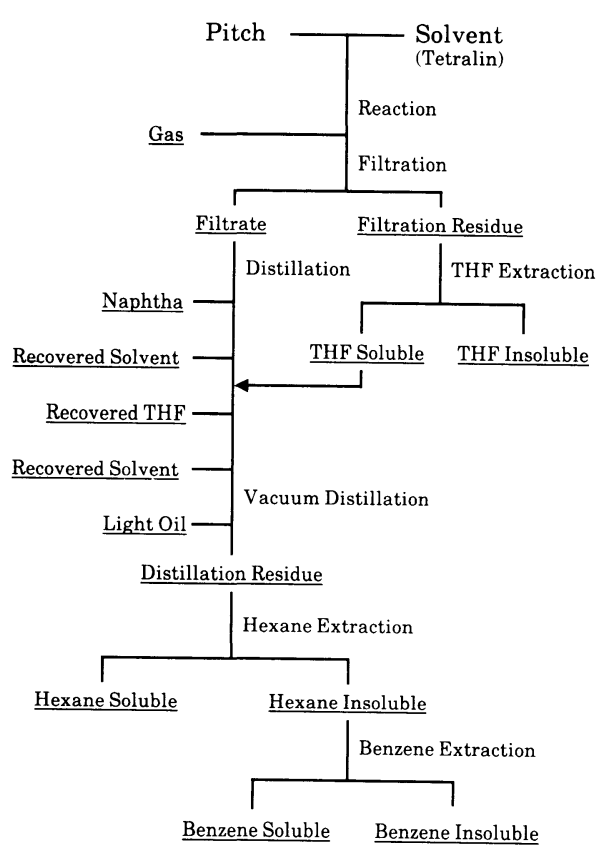

Fig. I Flow Sheet of Hydrogenated Treatment

were charged into a $500 \mathrm{ml}$ autoclave having titan inside tube equipped with a stirrer assembly. The atmosphere inside of the autoclave was replaced with nitrogen (1 atm).

The autoclave was heated at a rate of $10^{\circ} \mathrm{C} / \mathrm{min}$, and held at temperature of $410,430,450$ or $470^{\circ} \mathrm{C}$ for $60 \mathrm{~min}$. After the reaction, the gaseous product was analyzed by g.c. using a Unibeads A column. The mixture of liquid and solid products was separated by filtration, distillation and extraction, as shown in Fig. 1. The filtration residue was separated into THF-soluble and insoluble materials (THFIS) by extraction. The filtrate and THF extract were separated by distillation: naphtha (under $200^{\circ} \mathrm{C}$ ), solvent $\left(200-220^{\circ} \mathrm{C}\right)$, light oil $\left(220-350^{\circ} \mathrm{C}\right)$, and distillation residue $\left(>350^{\circ} \mathrm{C}\right)$. Naphtha, solvent and light oil were analyzed by g.c. using an OV-17 column. Then the distillation residue was separated by Soxhlet extraction into hexane-soluble materials (HS), hexane-insoluble but benzene soluble (HIS-BS), and benzeneinsoluble but THF-soluble materials (BIS).

\subsection{Radioactivity Measurement}

Specific activities of ${ }^{3} \mathrm{H}$ contained in these products were measured with a liquid scintillation counter. Colorless or light colored products were measured directly by dissolving them in the scintillator; but colored liquids, solids and gaseous products were oxidized to $\mathrm{H}_{2} \mathrm{O}$ to avoid color quenching.

The amounts of hydrogen added and exchanged were estimated as follows: The amount of hydrogen added from tetralin to pitch was calculated from the amounts of naphthalene, decalin and gaseous hydrogens produced on the basis of Eq. (1). The amounts of hydrogen exchanged between pitch and tetralin were calculated by subtracting the amount of hydrogen, which was added to pitch from tetralin, from the amount of hydrogen corresponding to the amount of tritium transferred to pitch on the basis of Eq. (2). The amounts of hydrogen transfers from solvent and pitch to gas phase were also calculated on the basis of Eqs. (3) and (4), in which it was assumed that radioactivities in gas phase were derived from gaseous hydrogen.

$$
\begin{aligned}
& H_{\mathrm{ad}}=4 N-H_{\mathrm{S} \rightarrow \mathrm{G}} \\
& H_{\mathrm{ex}}=\frac{H_{\text {int }} \times R_{\text {pitch }}}{R_{\text {total }}}-H_{\mathrm{ad}}
\end{aligned}
$$

$$
\begin{aligned}
& H_{\mathrm{S} \rightarrow \mathrm{G}}=\frac{H_{\text {int }} \times R_{\text {gas }}}{R_{\text {total }}} \\
& H_{\mathrm{P} \rightarrow \mathrm{G}}=H_{\text {gas }}-H_{\mathrm{S} \rightarrow \mathrm{G}}
\end{aligned}
$$

\begin{tabular}{|c|c|c|}
\hline & : the amount of naphthalene formed & [mol \\
\hline$f_{\text {ad }}$ & $\begin{array}{l}\text { the amount of hydrogen added from } \\
\text { solvent to coaltar pitch }\end{array}$ & \\
\hline$I_{\mathrm{ex}}$ & $\begin{array}{l}\text { : the amount of hydrogen exchanged } \\
\text { between solvent and coal tar pitch }\end{array}$ & \\
\hline int & $\begin{array}{l}\text { the initial amount of hydrogen in sol- } \\
\text { vent }\end{array}$ & \\
\hline $\mathrm{s} \rightarrow \mathrm{G}$ & $\begin{array}{l}\text { the amount of hydrogen transferred } \\
\text { from solvent to gas phase }\end{array}$ & \\
\hline $\mathrm{p} \rightarrow \mathrm{C}$ & $\begin{array}{l}\text { : the amount of hydrogen transferred } \\
\text { from pitch to gas phase }\end{array}$ & \\
\hline$H_{\text {gas }}$ & $\begin{array}{l}\text { the amount of gaseous hydrogen } \\
\text { in gas phase after reaction }\end{array}$ & \\
\hline & : total radioactivity & \\
\hline & radioactivity in pitch products & \\
\hline & radioactivity in gas phase & \\
\hline
\end{tabular}

\section{Results and Discussion}

The coal tar pitch for high performance carbon fiber (HPCF) was hydrogenated by a tritium labelled tetralin in the temperature range of 410 to $470^{\circ} \mathrm{C}$. The distributions of products at each reaction temperature are shown in Fig. 2 . The THFIS fraction in the raw coal tar pitch was $13.6 \mathrm{wt} \%$. In the temperature range of 410 to $470^{\circ} \mathrm{C}$, the THFIS fractions were about $5 \mathrm{wt} \%$ and did not change with rise in temperature. The distillation residue, including HS, HIS-BS and BIS fractions, was more than $80 \%$ in the temperature 


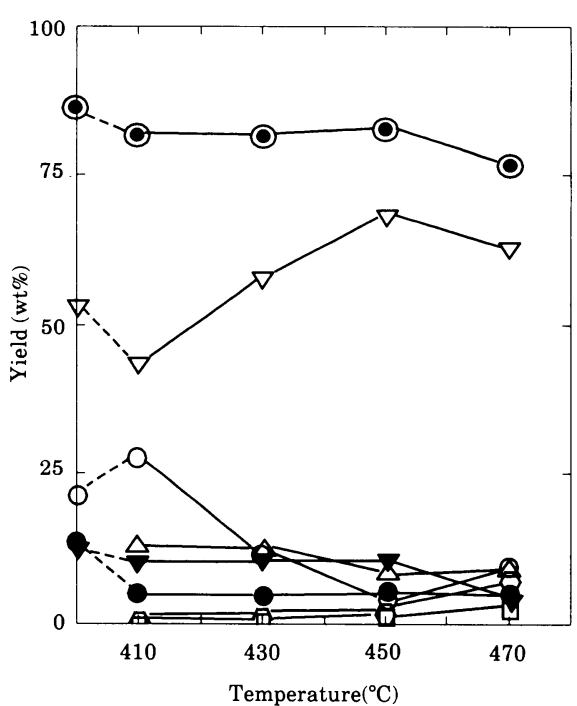

$\square$ : Gas, O: Naphtha, $\triangle$ : Light oil, O: Distillation residue (O: HS, $\nabla$ : HIS-BS, V: BIS), THFIS

Fig. 2 Distributions of Products (Symbols on a left vertical line represent raw pitch.)

range of 410 to $450^{\circ} \mathrm{C}$. In comparison with the case of the raw material, the HIS-BS fraction decreased and the HS fraction increased at $410^{\circ} \mathrm{C}$. Light oil was formed at $410^{\circ} \mathrm{C}$ while the BIS fraction did not change significantly. These show that the distillation residue fraction could be hydrogenated by tetralin solvent at temperature higher than $400^{\circ} \mathrm{C}$ in contrast with recent results which we obtained in the reaction of coal tar pitch with molecular hydrogen where polycondensation proceeded substantially ${ }^{12)}$. With rise in temperature from 410 to $450^{\circ} \mathrm{C}$, the HIS-BS fraction increased and the HS fraction decreased. These clearly show that the condensation of HS fraction would proceed to yield HIS-BS fraction in this temperature range. At $450^{\circ} \mathrm{C}$, HIS-BS reached the maximum, about $70 \mathrm{wt} \%$. In order to make good carbon fiber from a pitch, one should hydrogenate the pitch to increase HIS-BS fraction. In the present case, therefore, the best raw material to make good carbon fiber was obtained at $450^{\circ} \mathrm{C}$. On the other hand, the hydrocracking of coal tar pitch by tetralin also proceeded to increase gas and naphtha fractions with a rise in temperature from 410 to $470^{\circ} \mathrm{C}$ and to decrease BIS fraction at $470^{\circ} \mathrm{C}$.

The distribution of recovered solvent after the reaction is shown in Fig. 3. The amounts of naphthalene and methylindan formed increased with rise in temperature while the amount of decalin formed slightly increased. At $470^{\circ} \mathrm{C}$, about $10 \%$ of tetralin decomposed to naphtha fraction.

The distribution of tritium concentration in

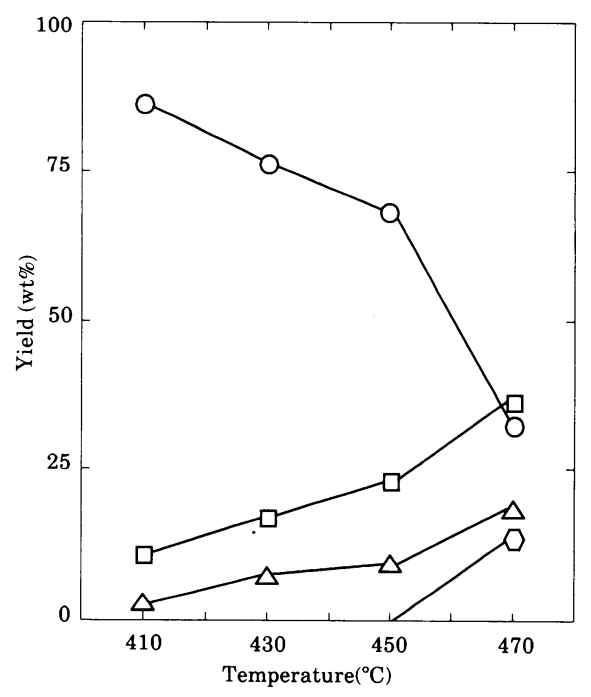

$\square$ : Naphthalene, $\bigcirc$ : Tetralin, $\triangle$ : Decalin and methylindan, $\mathrm{O}$ : Naphtha

Fig. 3 Distribution of Recovered Solvent

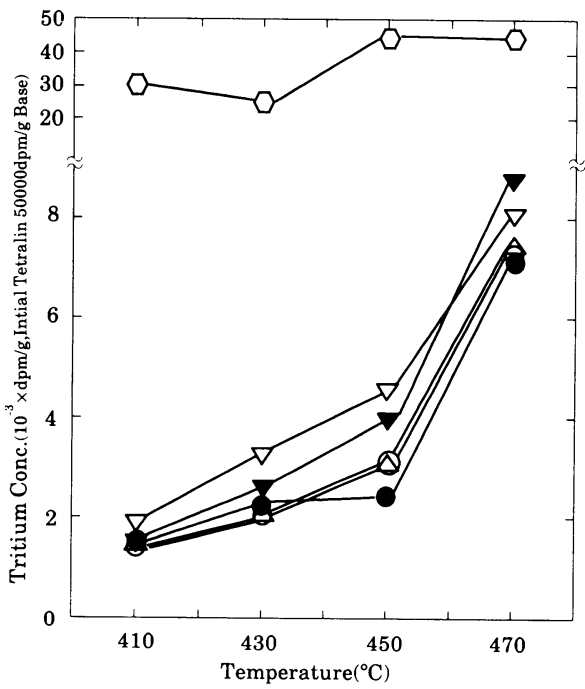

O: Naphtha, $\triangle$ : Light oil, O: HS, $\nabla$ : HIS-BS, V: BIS, O: THFIS

Fig. 4 Distributions of Tritium Concentration in Products

products is shown in Fig. 4. The tritium concentration in naphtha fraction was $30,000-$ $45,000 \mathrm{dpm} / \mathrm{g}$ greater than those in other fractions, in the temperature range of 410 to $470^{\circ} \mathrm{C}$. This indicated that the decomposition of tetralin to the naphtha fraction would proceed even at lower temperatures. The tritium concentrations in fractions other than naphtha increased with an increase in temperature.

The distribution of $\mathrm{C} / \mathrm{H}$ ratios in distillation residue, the THFIS fraction and the sum of these are shown in Fig. 5. The $\mathrm{C} / \mathrm{H}$ ratio in distillation 


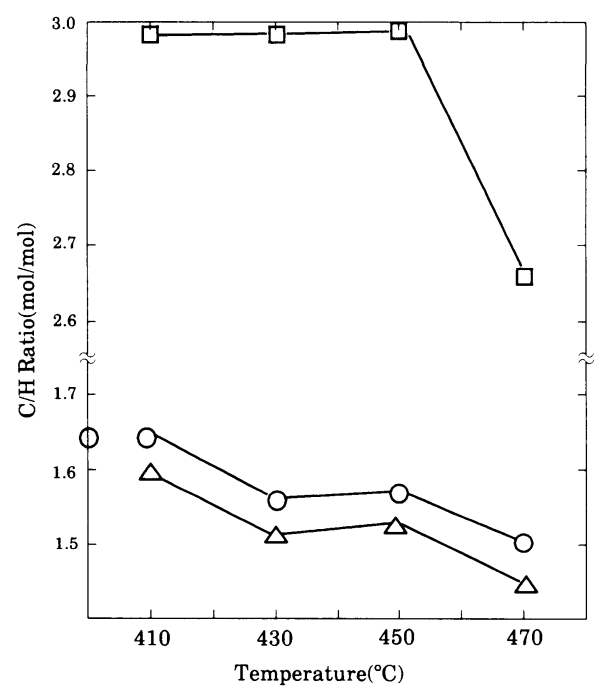

O: Distillation residue and THFIS, $\triangle$ : Distillation residue, $\square$ : THFIS

Fig. 5 Distributions of $\mathrm{C} / \mathrm{H}$ Ratios in Distillation Residue and THF Insoluble (A symbol on a left vertical line represents raw pitch.)

residue gradually decreased with rise in temperature from 410 to $470^{\circ} \mathrm{C}$, which shows that hydrogen molecules in tetralin were captured by the distillation residue. Although $\mathrm{C} / \mathrm{H}$ ratio in the THFIS fraction was about twice as high as that of the distillation residue, the $\mathrm{C} / \mathrm{H}$ ratio of the distillation residue and the THFIS fraction was low since the yield of the distillation residue was much greater than that of the THFIS fraction.

The balance of hydrogen transfer among three compositions, pitch, solvent and gas phase, are illustrated in Fig. 6. The amounts of hydrogen added and exchanged are represented by a solid line and a dotted line, respectively. The hydrogen contents in three phases after the reaction are shown in parentheses. As shown in Fig. 6, the amount of hydrogen release from either pitch or solvent to gas phase, which was calculated on the basis of Eqs. (3) and (4), increased with rise in temperature and the polycondensation of pitch seemed to increase with rise in temperature. In fact, the HS fraction decreased and the HIS-BS fraction increased with rise in temperature as shown in Fig. 2. The yield of HIS-BS reached the maximum at $450^{\circ} \mathrm{C}$. The amounts of hydrogen added from solvent to pitch were almost the same, however, and the amount of THFIS was kept constant in the temperature range of 410 to $470^{\circ} \mathrm{C}$. In our previous paper on the hydrogenation of coal tar pitch with gaseous hydrogen ${ }^{12)}$, the polycondensation proceeded, substantially, to increase THFIS fraction with rise in temperature from 300 to $400^{\circ} \mathrm{C}$ and prolonged time. In the present

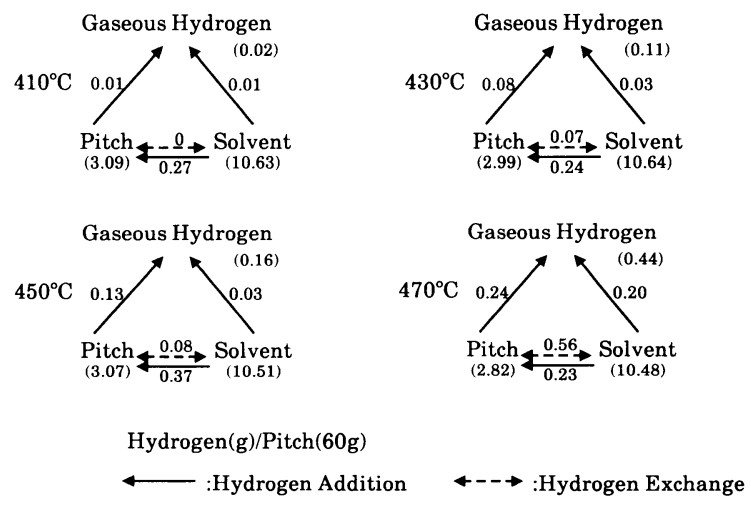

Fig. 6 Hydrogen Balance of Three Compositions (The amounts of hydrogen in each phase after the reaction are given in parentheses.)

hydrogenation of pitch with tetralin, on the contrary, the THFIS fraction was kept to a low value, even at $470^{\circ} \mathrm{C}$. These results suggest that there would be particular sites in the pitch which accepted hydrogen of tetralin and that tetralin would inhibit the increase of THFIS. The amount of hydrogen exchange between pitch and solvent increased significantly at $470^{\circ} \mathrm{C}$. Since the decomposition of tetralin proceeded substantially at $470^{\circ} \mathrm{C}$, it strongly suggested that radicals generated on tetralin would be related to the exchange reaction between pitch and tetralin.

In conclusion, although the release of hydrogen from pitch increased with rise in temperature, the increase of THFIS fraction was inhibited in the presence of tetralin and the yield of HIS-BS attained the maximum at $450^{\circ} \mathrm{C}$.

\section{References}

1) a) Ishikawa, T., Nagaoki, T., "Recent Carbon Technology", 27 (1980). b) Okuda,K., Kagaku to Kogyo, 35, 489 (1982). c) Mochida, I., Korai, Y., Nenryo Kyokaishi, 64, 796 (1985).

2) Collett, G. W., Rand, B., Fuel, 57, 162 (1978).

3) Patrick, J. W., Reynolds, M. J., Walker, A., Fuel, 62, 129 (1983).

4) a) Brooks, J. D., Taylor, G. H., "Chemistry and Physics of Carbon”, ed. by Walker Jr., P. L., Marcell Dekker, Inc., (1968), Vol. 4, p. 243. b) Brooks, J. D., Taylor, G. H., Carbon, 3, 185 (1965).

5) Shibaoka, M., Ueda, S., Russel, N. J., Fuel, 59, 11 (1980).

6) Mochida, I., Ueno, I., Korai, Y., Fujitsu, H., Sakatani, K., Sekiyu Gakkaishi, 30, (1), 31 (1987).

7) Yamada, Y., Sakawaki, K., Ida, S., Nippon Kagaku Kaishi, 1, 85 (1987).

8) Yamada, Y., Matsumoto, S., Fukuda, K., Honda, H., Tanso, 107, 144 (1981).

9) a) Kabe, T., Nitoh, O., Funatsu, E., Yamamoto, K., Fuel Processing Technology, 14, 91 (1986). b) Kabe, T., Yamamoto, K., Ueda, K., Horimatsu, T., Fuel Processing Technology, 25, 45 (1990).

10) a) Kabe, T., Nitoh, O., Marumoto, M., Kawakami, A., Yamamoto, K., Fuel, 66, 1321 (1987). b) Kabe, T., Nitoh, 
O., Funatsu, E., Yamamoto, K., Fuel, 66, 1326 (1987).

11) Kabe, T., Nitoh, O., Kawakami, A., Okuyama, S., Yamamoto, K., Fuel, 68, 178 (1989).
12) Okuyama, S., Shono, H., Ishihara, A., Kabe, T., Sekiyu Gakkaishi, 33, (3), 181 (1990).

要

旨

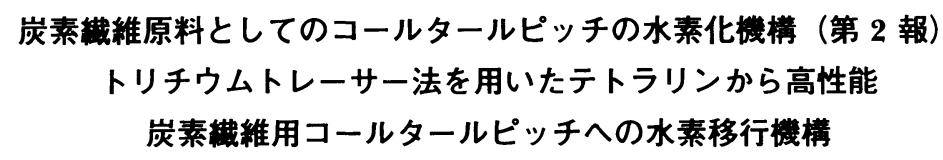

庄野弘晃 $^{\dagger 2)}$, 丸本 基 $^{\dagger 2)}$, 石原 篤 $^{\dagger 1)}$, 加部利明 ${ }^{\dagger 1)}$

†1) 東京農工大学工学部, 184 東京都小金井市中町 2-24-16

†2) 日東紡績(株)鈗物䋐維研究所, 960 福島市郷野目東

高性能炭素䋐維の原料となるコールタールピッチのテトラリ ンによる水素化反応機構をトリチウムトレーサー法により水素 の挙動および溶媒分別により生成物分布を調べることにより検 討した。反応はコールタールピッチ $60 \mathrm{~g}$ ，トリチウムでラベ ルしたテトラリン $120 \mathrm{~g}$, 反応温度 $410 \sim 470^{\circ} \mathrm{C}$, 反応時間 1 時間の条件で行った。溶媒分別には，へキサン, ベンゼン，お よびテトラヒドロフランを用いた（Fig. 1)。テトラリン中の 水素のピッチへの付加量およびテトラリンとピッチとの水素交 換量は Eqs. (1) および (2)により計算した。

トリチウムでラベルしたテトラリンの水素はコールタールピ ッチに移行した。Fig. 2 に生成物分布を示した。THFISは原 料ピッチ中に $13.6 \%$ 含まれているが $410^{\circ} \mathrm{C}$ で約 $5 \%$ まで減少

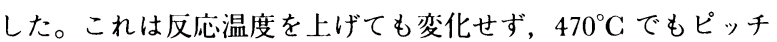
の重縮合による THFIS の增加は観祭されなかった。高性能炭 素䄉維原料となる HIS-BSは温度の上昇とともに増加し $450^{\circ} \mathrm{C}$ で最大となった。 $470^{\circ} \mathrm{C}$ では一部の溶媒が分解しナフサ が生成した (Fig. 3)。生成物中のトリチウム濃度は反応温度 の上昇とともに向上した (Fig. 4)。溶媒, ピッチ, 並びに気 相に放出された水素間の水素移行収支は Fig. 6 より，ピッ チ, 溶媒ともに気相への水素ガスの放出量が反応温度の上昇と ともに増加した。一方, 溶媒からピッチへの水素付加量は温度 によらずほぼ一定であった。このことは，ピッチ中にテトラリ ンの水素を受け入れる特定の場所があり, またテトラリンが THFIS の増加を抑制している可能性を示唆した。

\section{Keywords}

Tritium, Coal tar pitch, Tetralin, Hydrogenation, Carbon fiber 